CSABA VARGA*

\title{
Comparative Legal Cultures?
}

Renewal by Transforming into a Genuine Discipline

\begin{abstract}
Comparative law' was born to challenge national self-centredness at the turn of the 19th to 20th centuries, without transcending-notwithstanding its admission of social and cultural-historical approaches in the study of law-the perspectives of rule-positivism. 'Comparative legal cultures' attempts at explaining the prevailing cultural and traditional diversity that has generated, among others, western law with its modern formalism and the alternative ways of reaching social order in other cultures. By its focus upon the underlying culture and, thereby, also upon the hermeneutic understanding of legal phenomena, the latter is expected to offer growingly adequate responses to timely questions such as the universalisability of law and human rights, the convergence of the continental Civil Law and the British Common Law, or the development and future of the legal set-up in the Central and Eastern European region.

The interest of the comparative study of legal cultures is thus one in the history of ideas, dedicated to human problem-solving as the cultural response of people to external challenges. For the description of living complexes in terms of mere rules can result at most in 'thin description' with the exclusion of 'thick description', the more so as rules (just as concepts) are only the consequences of a kind of possible representation, therefore, relying exclusively upon them may contribute to dissolving even prevailing interrelations, atomising organic components as fragmented into detached elements. Or, institutional thinking notwithstanding, not even the subject's formalism can serve as a ground for restricting human completeness and integrity, cultural diversity, as well as responsibility to be taken for these.
\end{abstract}

Keywords: comparative law \& comparative legal cultures; law as text \& reduction of law to rules; understanding of socialist law \& transition to rule of law; rapprochment \& convergence of Civil Law and Common Law

\section{Legal Comparativism Challenged}

Human thinking is not only uninterruptedly continuous, but even when viewed as a process, it cannot be described otherwise than as a kind of oscillation. In this oscillation, besides power concentrations alternating with each other and

* Scientific Adviser, Institute for Legal Studies of the Hungarian Academy of Sciences, H-1250 Budapest POB 25; Professor, Director of the Institute for Legal Philosophy, Pázmány Péter Catholic University of Hungary [http://varga.jak.ppke.hu]

E-mail: varga@jak.ppke.hu 
adding up to wave crests and wave-troughs, any prevailing movement arises as a result of the ceaseless whirl of currents-and thereby drifts-coming from various directions. Routine and practical experience provide us some help from the past-forming a framework for our everyday action and, moreover, holding out promises of a perspective, a kind of illusory security-, however, in our presence at any given time, it is us who define fixed points for ourselves, in order to be able to arrange the entities at our disposal, as well as our concerns, into a kind of order at all. Therefore, when perceiving our ongoing occupations either as problem-solving or as acts of creative power, we have to be aware that, considered from a future perspective, all this may seem nothing other, or more ambitious, than just one of the episodes of stumbling from one blind alley into another.

What is, then, the proper way of cultivating scholarship at all? While looking for continuity from the past and for identity in the present, we are understandably conservative in designating our interest. When referring to our specific subject, we still speak of 'legal theory' in educational contexts, while we mention 'philosophy of law' at our biannual world congresses as accustomed since the founding act of the International Association for Philosophy of Law and Social Philosophy in Berlin in 1909; although the topics of subjects we teach and of scholarly papers we present do not recall, even in the way they pose a question or in their conceptual culture, the tradition acquired from previous generations in our youth. Namely, instead of "the system of legal sciences", of "legal axiology" or the "theory of legal relations", fashionable in the past decades, nowadays "semantics", "hermeneutics" and "legal reasoning" or "logical analysis of law" are customarily dealt with. For the issues related to the "concept of law" or "legal ontology and epistemology" have all become, if you like, outdated, archaic and irrelevant as traditional fields: the question of philosophical foundation has, for decades now, been replaced by the thrill of the social construction of reality ${ }^{1}$ that may lurk behind the scenes of manipulative applications we are

${ }^{1}$ For the term, see Berger, P. L.-Luckmann, Th.: The Social Construction of Reality. A Treatise in the Sociology of Knowledge. New York, 1966. Questions not properly considered up to the present are why and how the philosophical perspective and the requirement for thorough foundation have disappeared from our legal thinking over the past few decades, and what they have been or are going to be replaced by, if at all. From the British analytical jurisprudence (e.g., H. L. A. Hart, J. Raz and N. MacCormick) to the American and Western European theories of reasoning (e.g., R. M. Dworkin on the one hand, and A. Aarnio, R. Alexy and A. Peczenik on the other), law is simply taken as given in an unquestioned culture, as are the social values and the culture of reasoning, held as specifically characteristic of a given community. By supposing their having been accepted from the very start, the task of legal theory now seems to be simply confined to raising 
nowadays driven to incessantly search for. For what else could the way of scholarly interest be? All we can try is to respond to renewed challenges which-alongside new considerations, methodologically proven statements and conceptual distinctions-launch new waves and provoke currents, while the actors in the debates among the various positions emerging within these mostly turn back only very rarely and randomly to viewpoints, considerations and arguments dismissed as unworthy of further debate earlier in the discussion, and which viewpoints, consequently, had drifted away from the mainstream.

The same holds true of the comparison of laws which emerged as part of the comprehensive movement of comparativism by the advent of the "age of comparison", as Nietzsche once rightly noted. ${ }^{2}$ When the inquiry into the various particularities of human construction, community language, national law (etc.) proved too limited to develop further towards the end of the 19th century in the cult of positivism, "comparative anatomy", "comparative linguistics" and "comparative jurisprudence" emerged as a result. Of course, this could only imply a radical change away from the normal course of development, where also the self-closing retirement into the subject's own particularity was most determinedly pushed to the extreme. Accordingly, it is not by chance that it was France, the native land of national chauvinism, to become the centre of comparative jurisprudence, and the European continent became preferred as its number one field of investigation. However, all the comparative movement in law has proved to be a non-recurrent task. In its turn, the very mention of such non-recurrence involves the recognition that, in the history of thinking, "isms" in general are inevitably bound to be assimilated step by step into and eventually absorbed by human thought in formation: as soon as the revolting breakthrough is made and reformatory thought is accepted, it ceases to survive as a separate entity. Just as present-day debates do not use terms of, e.g., Platonism or structuralism any longer, there is no specific need to explain why we resort to and call for-among others-comparison in our scholarly work. It is enough to note, maybe, that it is no longer usual for any monographic treatment of legal topics to be done without a genuine comparative-historical approach in the background.

Well, as far as the association of qualifying terms 'comparative' and 'historical' is concerned, only our once characteristic narrow-mindedness and

awareness to, by explaining and developing also in details of interrelations, the human manipulative practice shaping the law in action. As a particularly telling panorama, see Luc, J.-Wintgens, L. J. (ed.): The Law in Philosophical Perspectives. My Philosophy of Law. Dordrecht-Boston-London, 1999.

2 Nietzsche, F.: Humain, trop humain [1878]. Paris, 1988. 49-50. 
our self-closing into national boundaries in legal scholarship can explain why our Civil Law predecessors on the European continent had to emphasise, in their one-time breakthrough, the necessity of comparison (and not that of historicity) as being most in need of development. For historical jurisprudence, evolving around the middle of the 19th century within the Common Law as a follow-up of legal development generated by the practice of judicial decisions (having been cumulated one upon another as judicial precedents), was an entirely natural outcome ${ }^{3}$ moreover, due to the shift of emphasis in the practical life of law to the search for judicial reason that arrives at declaring what the law is through a specific methodology of problem-solving, jurisprudence was not urged to transcend national borders, as it already achieved to carry out free search for similar sources in its quest for meaning, on the one hand. On the European continent and especially in France, on the other, the emphasis had for long been centred on the legislator as the representative and symbol of a national will and, therefore, any legal development could only be considered a national accomplishment. This is the reason why, with us, historical interest was gradually left out of the topicality of positive law, to form some complementary and additional subject as a separate discipline, both external to and irrelevant for everyday practice.

As noticed above, having achieved the breakthrough, legal comparativism has lost its specific function. For a moment, let us contemplate: if every analysis is already based on a historico-comparative approach, whoever would need a particular movement suitable just to force open doors? Continental positivism as the scholarly stand based upon the exclusive moment of statutory textenactment became to a certain extent antiquated by the first third of the 20th century anyway and, by the middle of the same century, the emphasis shifted firmly to the judicial process which was also to involve moments of social and cultural conditioning, thereby opening the gates to textual hermeneutics. Step by step, the text-positivism of the one-time legislatory definition of the law ${ }^{4}$ and also the sociologism relating to the law's social environment ${ }^{5}$ have eventually

${ }^{3}$ Cf. Szabadfalvi, J. (ed.): Historical Jurisprudence. Budapest, 2000. 14-35 and 281285 , respectively.

${ }^{4}$ Cf., e.g., Varga, Cs.: Codification as a Socio-historical Phenomenon. Budapest, 1991., especially ch. V. paras. $2 / \mathrm{a}$ and 4 , introducing on the example of the classic type-framing Code civil (1804), how the definition of the law through legislatorial text in the juridical exegesis, characteristic of the early 19th century, has become gradually reduced to the role of providing a merely referential framework and disciplinary medium for the otherwise growingly free judicial declaration of what the law should be and/or is.

5 It is remarkable that anything in germ of a sociology of law had been heralded in parallel with the theoretical assertion of legal positivism, when two professors with same 
been replaced by the open-chanced pondering of any (con)texture of the present, in which the questions "from where?" and "what?" are increasingly substituted by the ones of "how?" and "to what?".

Even in the field of law, the scene of our everyday life no longer seems to be just a case of determinations, but the starting point of creative and decisive switchings actually effected by each of us at any moment in those several roles we play, and thereby also the free medium for the manipulation of everything we have appropriated from our environment. As a consequence of all the above, the increase in awareness of the multiple and thorough repercussions of the humanities as a scholarly tradition upon the law and the requirement of social theoretical approach in legal thinking, the examination of law in parallel with other social regulative forces, as well as the adoption of an anthropological perspective (in the light of which law seems to be just one of the possible representations of the ideal of order required for any social formation), well, all these have led to a change in the search for specificity in law more powerfully in the context of culture as a whole (or, more precisely, in the context of the cultural response we offer in law to the various challenges, characteristic of the given human community and civilisation). ${ }^{7}$

backgrounds in Vienna, Hans Kelsen, formulating in theory the self-defining self-identification of positive law, on the one hand, and Eugen Ehrlich, appointed to the new university of Czernowitz and theorising upon his new experience relating to the mess of co-existing folks and laws in Bukovina and Galicia in order to finally realise the empirical justifiability of some "living law" with no official support whatsoever in the background, on the other, contrasted sociologism and positivism in legal thinking. For the debate in Archiv für Rechts- und Wirtschaftsphilosophie from 1916 to 1917, see Stanley L. Paulson (hrsg.): Hans Kelsen und die Rechtssoziologie. Aalen, 1993.

6 For the theoretical background, cf. Varga, Cs.: An Inquiry into the Nature of the Judicial Process. In I[nternationales]R[echts]I[nformatisches]S[ymposium] 2006 Proceedings [Vienna, February 2006] \{A bírói folyamat természetének kutatása. Jogtudományi Közlöny XLIX (1994) 11-12, 459-464\} and, in monographic treatment, his Theory of the Judicial Process The Establishment of Facts. Budapest, 1995. as well as his The Context of the Judicial Application of Norms, in: Krawietz, W.-MacCormick, N.-von Wright, G. H. (ed.): Prescriptive Formality and Normative Rationality in Modern Legal Systems, Festschrift for Robert S. Summers. Berlin, 1994. 495-512 [for paras. i-ii] and Law, Language and Logic: Expectations and Actual Limitations of Logic in Legal Reasoning, in: Ciampi, C.-F. Socci Natali-G. Taddei Elmi, I (ed.): Verso un sistema esperto giuridico integrale. Padova, 1995. 665-679.

${ }^{7}$ For a theoretical justification and background, cf. Varga, Cs.: A jog mint kultúra? [Law as culture?] Jogelméleti Szemle 2004/3 <http://jesz.ajk.elte.hu/varga11.html> as well as Macrosociological Theories of Law: From the »Lawyer's World Concept « to a Social Science Conception of Law. In: Kamenka, E.-Summers, R. S.-Twining, W. (ed.): 


\section{Comparative Legal Cultures versus Comparative Law}

As a consequence, the starting point is no longer either the law of a nation or its sectoral history, but the cultural medium in continuous formation, in which references, as the fixed and fixing points of human thinking and action-beliefs and values, preferences and aims, traditions and skills, methods and proceduresmay have developed in a given (and not another) way, that is, the medium in which a certain (and not another) notion of order and the associated (and not another) store of instruments (with a proper conceptual scheme and the role it may attribute to abstract logic) could evolve. If, in an inverse move, we start thinking from the endpoint, this explains why the comparative study of legal cultures neither supposes any kind of codified list, nor any set of questions, nor taxonomy, nor previously established methodology, regarding (or following) which the discipline of comparative legal cultures and its focus on the whole variety of cultures and ages should provide a response. Just to the contrary. According to its inherent approach, out of itself and through its in-built learning processes, each culture generates proper (general and sectoral) formations, frameworks and schemes, often ones and in manners characteristic exclusively of it-approaches and problem-sensitivities, organisational principles and notional distinctions, institutionalisations and procedural paths, methods and skills-, which are suitable, in their systemic totality, to define the specific character of an order which is going to be described by us a posteriori as a legal one, particular to the given culture.

By this point, we can claim to have indeed arrived, from the classical movement known as 'comparative law', at the cultivation of 'comparative legal cultures'. For our inquiry neither stays within the boundaries of law, nor does it start from an analysis of the available store of positive legal instruments, nor is it determined by the latter. For the most part, it concentrates neither on our ongoing present, nor wishes to contrast the formalised institutions-provided that they can be related at all-of certain nations to those of others. Instead, it attempts, with a cultural anthropological focus, to examine different possibilities (potentials and availabilities) as historically formed alternatives from a civilisational developmental perspective. The question here is exactly why a particular (and not another) legal idea and institutionalisation emerged in a given medium. And

Soziologische Jurisprudenz und realistische Theorien des Rechts. Berlin, 1986. 197-215. [Rechtstheorie, Beiheft 9] and Macrosociological Theories of Law: A Survey and Appraisal. Tidskrift för Rättssociologi III (1986) 3-4, 165-198. 
the question it intends to answer is: why and how a certain (and not another) store of instruments has developed in the given place and time from all of this? ${ }^{8}$

'Comparative legal cultures'? How have we arrived at this very term? The linguistic expression itself is obviously a derived further development from the disciplinary term of 'comparative law' as widely accepted today. For this very reason, justified criticism for the former relates and applies to the latter as well. For it should be admitted that in their literal senses both the basic term and its derivation are, properly speaking, meaningless (and entirely alien to the very spirit of language), as contrasted to the properly compounded French terms droit comparé ['compared law'='law that is compared, i.e., taken in comparison'] and cultures juridiques comparées. Despite this all, it is still capable of easy identification, and it is obvious for everyone that it is, by its very meaning, nothing other than a simplified and shortened version for the complex expression of the 'comparative study of law [and, respectively, of legal cultures]'.

Apart from the rudimentary recognition of the obvious truth according to which "every national law should be explained as a proper part of human culture", 9 the movement of comparative law neither sought nor realised anything other than its own release from the national seclusion of domestic legal positivisms. Although the worldwide leading classic of legal comparativism from our recent past rightly claimed that

"the comparison of laws is an important general cultural means for the lawyer, without which-and without the historical background serving as its completion and homologue-one cannot arrive at conclusions beyond the sphere of the given law and thus at a universality required of any genuine scholarship", 10

the discipline has not subsequently become anything more than a sheer methodhowever necessary it may be for any scholarly result to be reached-, selected

8 As a former research project proposal by the author, see his A jog és történelmi alternatívái [Law and its historical alternatives]. [1982] in: his Útkeresés Kísérletek kéziratban [Searches for a path: unpublished essays]. Budapest, 2001. 127-131.

9 Kohler, J.: Über die Methode der Rechtsvergleichung. Zeitschrift für das Privat- und öfentliche Recht der Gegenwart XXVIII (1901), 273-284.

${ }^{10}$ David, R.: Le droit comparé, enseignement de culture générale. Revue internationale de Droit comparé II (1950), 682-685. Cf. also Péteri, Z.: Some Aspects of the Sociological Approach in Comparative Law, in: Péteri, Z. (ed.): Droit hongrois - droit comparé Études pour le VIII ${ }^{\mathrm{e}}$ Congrès international de droit comparé. Budapest, 1970. 75-94. 
out from the obviously desirable methodological complexity. In addition to the fact that bi- and multilateral comparisons of national laws have since (and largely due to this very movement) become accepted in scholarship, its fundamental and imperishable merits include having drawn up the actual ${ }^{11}$ and intellectually processed and historically developed ${ }^{12}$ global map of the world's legal systems $;{ }^{13}$ having taken the pioneering initiative of elaborating categories used for classifying (by drawing "family resemblances" for) the various legal orders and arrangements, together with having undertaken a largely static, descriptive presentation of the laws and orders on both a universal and especially a European

${ }^{11}$ See, e.g., Randall, H. J.: Law and Geography. In: Kocourek. A.-Wigmore, J. H. (ed.): Evolution of Law Select Readings on the Origin and Development of Legal Institutions III. Formative Influences of Legal Development. Boston, 1918. ch. 6; Wigmore, J. H.: A Map of the World's Law. The Geographical Review 19 (1929), 114-121 [starting from the statement that nine-tenth of the Earth's population is governed by a dozen of laws, among which the Anglican, the Germanic, the Hindu, the Islamic, the Japanese, the Chinese, the Romanesque and the Slav ones continue exerting mass influence, while the Egyptian, the Greek, the Hebrew, the Canon, the Celtic, the Mesopotamian, the Roman and the maritime laws have in their original quality disappeared since]; Desserteaux, M.: Droit comparé et géographie humaine. Annales de Géographie LVI (1947), 81-93. [mostly identifying European legal ideas with their Christian roots "at present actually extant too" (83, note 2, as well as 85); and placing, in a remarkable way, the "mixed Roman method" between the "German" deductivism and the "English" inductivism, which, in case the statutory solution is deficient, applies, in addition to the deductivity of inferences from statutory dispositions, subsidiary empirical constructions inductively (in French, Spanish or Swiss law) or relies on French jurisprudence as a suppletive source (in Belgian or Rumanian law) (86); and foreseeing a joint intermediate method as the proper future solution for Europe (92)]; David, R.: La Géographie et le Droit. La Revue de Géographie humaine et d'ethnologie 2 (1948), 78 et seq.; Sand, P. H.: Current Trends in African Legal Geography The Interfusion of Legal Systems. New York, [1971]. 27.; E. S. Easterly, III: Global Patterns of Legal Systems: Notes Toward a New Geojurisprudence. Geographical Review 67 (1977), 209 et seq.; Guelke, L.: The Role of Laws in Human Geography. Progress in Human Geography 1 (1977), 376 et seq.; Economides, K.-Blacksell. M.-Watkins, Ch.: The Spatial Analysis of Legal Systems: Towards a Geography of Law? Journal of Law and Society 13 (1986) 161-181.

${ }^{12}$ See, e.g., Wigmore, J. H.: A Panorama of the World's Legal Systems I-III. St. Paul, Minn. 1928

${ }^{13}$ For a historical overview, cf. Varga Cs.: Theatrum legale mundi avagy a jogrendszerek osztályozása, in: Szilágyi, I. H.-Paksy, M. (ed.): Ius unum, lex multiplex Liber Amicorum: Studia Z. Péteri dedicata (Studies in Comparative Law, Theory of State and Legal Philosophy). Budapest, 2005. 219-242. and On the Classification of Legal Systems [Abstract], 243-244. 
level. ${ }^{14}$ In this way, it has succeeded in raising the awareness of the relativity, the uniqueness, as well as the considerably accidental character of the various national legal orders, taken as the exclusive subject of jurisprudence since the classical age of the codification of national laws.

To the luck of us all, introduction to the main legal systems of the world under the heading of "comparative law" has become almost a sine qua non of legal education; as an independent scholarly trend, however, it soon became exhausted. Scholars and critics have for decades now been constantly complaining of its being "obstinately repetitive and sterile", ${ }^{15}$ of its having a "precarious character" 16 of a "mediocre quality" ${ }^{17}$ resulting in "disappointing" "theoretical misery", 19 ending in "marginalisation" 20 and "superficiality", all in all, in methodological and theoretical "failure", ${ }^{22}$ rightly "plagued by the absence of any sustained theoretical reflection on [...] that comparative law is nothing more or less than a methodology". ${ }^{23}$ As an expression of this depreciation through

${ }^{14}$ E.g., Schlesinger, R. B.: Comparative Law Cases and Materials. Brooklyn-London, 1950.; David, R.: Traité élémentaire de droit civil comparé Introduction à l'étude des droits étrangers et à la méthode comparative. Paris, 1952.; Arminjon, P.-Nolde, B.-Wolff, M.: Traité de droit comparé I-III. Paris, 1950-1952.; Schnitzer, A.: Vergleichende Rechtslehre. Basel, 1945. [I-II, Zweite Aufl. (Basel, 1961)]; David, R.: Les grands systèmes de droit contemporains. Paris, 1964.; Duncan, J.-Derrett, M. (ed.): An Introduction to Legal Systems. London, 1968.; Zweigert, K.-Kötz, H.: Einführung in die Rechtsvergleichung auf dem Gebiete des Privatrechts, I [Grundlagen]-II [Institutionen]. Tübingen, 1971-1969.; Constantinesco, L. J.: Rechtsvergleichung I-III. Köln, 1971-1972.; David, R. et al. (ed.): International Encyclopedia of Comparative Law. Tübingen, 1973-1985.; Rheinstein, M.: Einführung in die Rechtsvergleichung. München, 1974.; Eörsi, Gy.: Comparative Civil (Private) Law Law Types, Law Groups, the Roads of Legal Development. Budapest, 1979.; Rodière, R.: Introduction au droit comparé. Paris, 1979.; Schlesinger, R. B.-Baade, H.-Damaska, M. R.-Herzog, P. E.: Comparative Law Cases-Text-Materials. $5^{\text {th }}$ ed. Mineola, N. Y., 1988.; Bogdan, M.: Comparative Law. Deventer-Cambridge, 1994.; Fromont, M.: Grands systèmes de droit étranger. $2^{\mathrm{e}}$ éd. Paris, 1994.

${ }^{15}$ McDougal, M. S.: in The American Journal of Comparative Law I (1952), 29.

${ }^{16}$ Hall, J.: Comparative Law and Social Theory. Baton Rouge, 1963. 6.

${ }^{17}$ Rigauxm F.: in Revue du Droit international et de Droit comparé XXX (1978), 73.

${ }^{18}$ Shapiro, M.: Courts. Chicago, 1981. vii.

${ }^{19}$ Constantinesco, L.-J.: Traité de droit comparé. III. Paris, 1983. 21.

${ }^{20}$ Frankenberg, G.: Critical Comparisons: Re-thinking Comparative Law. Harvard International Legal Journal 26 (1985) 2.

${ }^{21}$ Watson, A.: Legal Transplants. 2nd ed. Athens-Georgia, 1993. 10.

${ }^{22}$ Legrand, P.: Comparative Legal Studies and Commitment to Theory. Modern Law Review 58 (1995), 262.

${ }^{23}$ Samuel G.: Comparative Law. In: Gray, Ch. B. (ed.): The Philosophy of Law An Encyclopedia. New York-London, 1999. 137. 
external evaluation, it has recently been omitted from a collective representation of social sciences, not being listed as one of the many international comparativisms taken into account. ${ }^{24}$ In addition to rewriting the above mentioned map time and again and to promoting legal borrowing and the law's adaptation, ${ }^{25}$ the most important of its tasks today is to serve the harmonisation and the prospective unification of laws and also the codification of a common European private law. In its turn, all this reinforces the discipline exactly in its standing decisive features, namely, at a focus on prevailing (valid and effective) regulations, its reliance upon positive law and handling the law as a given and ready-made instrument.

In contrast to the classical stance of comparative law, the comparative study of legal cultures has from the very start been interested in the genesis and formation of the law's various phenomena and operations, that is, in how law evolved within various civilisations, producing various cultural responses in human efforts at problem solving, with varying moral and religious foundations and value preferences in successive ages in a way rebuilding again and again. Or, this is also an interest in the history of ideas, manifesting itself in the general frame of the history of civilisations, dedicated to societal problem-solving capacity even when we are making formal and homogenised instruments and institutions, to arrive at a picture of the evolutionary progress sometimes taken as traditional history, characteristic of the given civilisation(s), ${ }^{26}$ or to arrive at a

${ }^{24}$ The special issue of La Revue européenne des Sciences sociales (1986) mentioned only anthropological, economic, linguistic, psychiatric, religion-historical and sociological comparativisms as living. For the above criticism of comparative law, see especially Legrand, P.: Le droit comparé. Paris, 1999., passim, particularly at 8.

25 "Borrowing from abroad has become a recognised legislative practice in most contemporary states." Sand: Current Trends in African Legal Geography. op. cit. 24. We have widely recognised since the elaboration of "cultural patterns" by Lévy-Strauss, C.: Les tristes tropiques. Paris, 1955.-that "the comparatively rapid growth of human culture as a whole has been due to the ability of all societies to borrow elements from other cultures and to incorporate them into their own." Linton, R.: The Study of Man An Introduction. New York, 1936., 324. For a critical overview with a critical assessment, cf. Varga, Cs.: Transfers of Law: A Conceptual Analysis, in: Mamoru Sadakata (ed.): Hungary's Legal Assistance Experiences in the Age of Globalization. Nagoya, 2006. 21-41. \{with an abstract-Reception of Legal Patterns in a Globalising Age-in: Jiménez, J. J.-Gil, J.Peña, A. (ed.): Law and Justice in a Global Society. Addenda: Special Workshops and Working Groups (IVR 22nd World Congress, Granada, Spain, 24-29 May 2005). Granada, 2005. 96-97.\}.

${ }^{26}$ E.g. Fikentscher, W.-Franke, H.-Köhler, O. (ed.): Entstehung und Wandel rechtlicher Traditionen. Freiburg-München, 1980.; Jesús Lalinde Abadía: Las Cultures represivas de la humanidad (H. 1945) I [Adat y otras (pueblos infraevolucionades), Darma (Sudeste 
cultural anthropological explanation of the legal choices we make, ${ }^{27}$ or to arrive at the construction of a comparative functional representation of the actual state that can be concluded from the practical appearance, utilisation and enforcement of the law through the sociological description of the medium by, and within, which law is conditioned and operated. ${ }^{28}$

Obviously, another ethos, another interest and another problem-sensitivity are at work here when they are related to the ones employed in the pioneer age of comparison. The path is evidently not already paved, and-instead of mere intellectual arguing-a new trail can only be broken if we set out on it. "Those who can, do it, those who cannot, explain it"-despite its one-sided injustice, this traditional wisdom tells a lot about the one-time Prussian pattern, so deeply ingrained in the socialist regime imposed upon us, thoroughly overideologised. For we know: in huge parts of Moscow-dominated Eastern and Central Europe, cultivation of scholarship was virtually impossible, yet lengthy explanations introducing emptied textbooks proudly declared the abstract aspiration for a scholarly quality in the foursome of subject, method, structure, and purpose, which were set in stone. "Too much argumentation kills the deed"every thinker is expected to assume personal conviction and humility so that even if he is quite uncertain or formulates sheer presumptions, he shall cover the entire path of cognition.

An open question is, therefore, what the student of comparative legal cultures can achieve over the long run. Another question is the assessment of the reserves inherent in the bulk of fragmented studies comparing legal cultures, which have been published so far. A number of papers, coming from

asiático), Chíng (Extremo Oriente), Meecharu (Oriente Medio), Maat (Antiguo Egipto), Díke (Antigua Grecia), Ius (Roma-Biyancio), Torá (Judíos), Charía (Árabes)] - II [Directum (Europa latina e Iberoamérica), Reht (Europa germánica), Jog (Hungría), Prawo (Europa eslava), Common law (Mancomunidad anglo-sajona)]. Zaragoza, 1992.; and, most recently, Glenn, H. P.: Legal Traditions of the World Sustainable Diversity in Law. Oxford, 2000. For the last title, cf. also Varga Cs.: Legal Traditions? In Search for Families and Cultures of Law. Acta Juridica Hungarica 46 (2005), 177-197.

${ }^{27}$ In addition to the first title in note 29, cf. also Feest, J.-Blankenburg, E. (ed.): Changing Legal Cultures. Oñati, 1997.; Nelken, D. (ed.): Comparing Legal Cultures. Aldershot, 1997.; Feest, J.-Nelken, D. (ed.): Adapting Legal Cultures. Oxford, 2001.; Bell, J. (ed.): Comparative Legal Cultures. [Aldershot: Dartmouth (in preparation)].

${ }^{28}$ E.g., by Blankenburg, E.: Legal Cultures Compared, in: Ferrari, V. (ed.): Laws and Rights. Bologna, 1991. 93-101., Culture juridique comparative, in: Arnaud, A.-J. (ed.): Dictionnaire encyclopédique de théorie et de sociologie du droit. $2^{\mathrm{e}}$ éd. Paris, 1993. 141142. and Civil Litigation Rates as Indicators for Legal Cultures, in: Comparing Legal Cultures. op. cit. 41-68. 
the discipline of 'comparative law' strictly taken and, labelled as irrelevant, neither collected, nor studied by genuine comparativists, have, notwithstanding, investigated certain culturally relevant legal issues.

\section{Contrasting Fields}

Interestingly enough, the route I have tried to explore ${ }^{29}$ has received confirmation (thought-provoking themselves, and opening up new prospects as well) from most unexpected quarters in the recent past. In an attempt to describe the legal systems of Central and Eastern European countries now on the path of their transition to the rule of law, ${ }^{30}$ on the one hand, and in an effort to challenge the allegedly spontaneous convergence of the historical blocks of Civil Law and Common Law development, to be completed anyway through the European legal rapprochement, ${ }^{31}$ on the other, it has been noted that the "dogmatically entrenched and thoughtlessly transmitted preconceptions" of classical comparative law (which "often operate as false generalisations and universalisations of what are, in fact, little more than localised, western-liberal perspectives" ${ }^{\text {"32 }}$ ), owing to their "epistemological barrier", ${ }^{33}$ actually close down and block the way to cognition, instead of opening up and paving-by substantiating-it. For reducing law to mere rules not only transmits an image which falsely represents legal experience ${ }^{34}$ but, by its search for rationality, foreseeability, certainty, coherence, and clarity at any price, it also "strikes a profoundly antihumanist note". ${ }^{35}$ By reducing the complexity of the law's actual operation to

${ }^{29}$ Varga, Cs. (ed.): Comparative Legal Cultures. Aldershot-Hong Kong-SingaporeSydney-Dartmouth-New York, 1992., as well as Varga, Cs.: Comparative Legal Cultures: Attempts at Conceptualization. Acta Juridica Hungarica 38 (1997), 53-63.

${ }^{30}$ Puchalska-Tych, B.-Salter, M.: Comparing Legal Cultures of Eastern Europe: The Need for a Dialectical Analysis. Legal Studies 16 (1996) 2, 157-184.

${ }^{31}$ Legrand, P.: European Legal Systems Are not Converging. The International and Comparative Law Quarterly 45 (1996), 53-81.

${ }^{32}$ Puchalska-Tych-Salter: Comparing Legal Cultures of Eastern Europe... op. cit. 159.

${ }^{33}$ Legrand: European Legal Systems Are not Converging. op. cit. 60. For the concept of "obstacle épistémologique", see Bachelard, G.: La formation de l'esprit scientifique Contribution à une psychanalyse de la connaissance objective, $14^{\mathrm{e}}$ éd. Paris, 1989.

${ }^{34}$ Cf. Salter, M.: The Idea of Legal World. International Journal of the Legal Profession 1 (1994), 291-295.

${ }^{35}$ Puchalska-Tych-Salter: Comparing Legal Cultures of Eastern Europe... op. cit. 179, as well as Legrand: European Legal Systems Are not Converging. op. cit. 60. 
the static and abstract formalism of one given official state doctrine, ${ }^{36}$ classical comparative law can at the most reproduce such complexity only in a superficial and simplifying way. ${ }^{37}$

\section{a) The Historical Understanding of Socialist Law}

As far as socialist law is concerned, 'comparative law' had-as the above mentioned British comparatists claim-generated a quite artificial concept upon the basis of an ideal type that had never actually existed anywhere. For it reduced various national legal systems with differing historical backgrounds and developmental abilities to one common denominator ${ }^{38}$ upon the basis of Muscovite-type imperialism alone (while formulating, in a sanctimonious way, an implicit theoretical justification for the then convenient Western politics of submissiveness). Ironically-shall we add-the collapse of communism was necessary for Western complacency eventually to realise that Westerners had seen something of themselves in socialism, while they easily ignored the features that had made communism so inhumane, destructive, unbearable and fatal as it was. For instance, never having been able to overcome its own domestic everyday routine in due time, the West used to consider outward appearances (of mere verbal declarations in the law of posited texts) as actually effective and legally enforced normative contents of socialist law. ${ }^{39}$ Therefore, it did not

\footnotetext{
${ }^{36}$ Since its classical European definition-in Weber, M.: Rechtssoziologie (1960) and Kelsen, H.: Reine Rechtslehre (1934)-, the very concept of legal formalism has acquired a function of constituting criterion also in American theoretical literature. Cf., e.g., Weinrib, A.: Legal Formalism. The Yale Law Journal 96 (1988), 949 et seq.; Shauer, F.: Formalism. The Yale Law Journal 97 (1989), 509 et seq.; McBarnet, D.-Whelan, C.: The Elusive Spirit of the Law: Formalism and the Struggle for Legal Control. Modern Law Review 54 (1991), 848 et seq.; Summers, R.-Atiyah, P.: Form and Substance in Anglo-American Law. New Haven-London, 1987.

${ }^{37}$ Puchalska-Tych-Salter: Comparing Legal Cultures of Eastern Europe... op. cit. 183.

${ }^{38}$ Ibid., para. 2, 164-174.

${ }^{39}$ For the stubborn dominance of such a non-realisation and non-awareness having done, with its blindness, serious harms to the peoples in the Central and Eastern European region until the change of regimes controlled by the West was effected, see, by Varga Cs.: Transition to Rule of Law On the Democratic Transformation in Hungary. Budapest, 1995. as well as Önmagát felemelö ember? Korunk racionalizmusának dilemmái [Man elevating himself? Dilemmas of rationalism in our age], in: Mezey, K. (ed.): Sodródó emberiség [Humankind adrift]. Budapest, [2000], 61-93; with a theoretical explanation, Rule of Law At the Crossroads of Challenges. Iustum, Aequum, Salutare [Budapest] I (2005) 1-2, 73-88; and for western papers with the same realisation (as translated into Hungarian), also Varga, Cs. (ed.): Kiáltás gyakorlatiasságért a jogállami átmenetben [A call for practicality in the transition to rule of law]. Budapest, 1998.
} 
believe the conceptual attempts either which criticised socialism upon the recognition of its nature as a culture built on sheer lying, i.e., on dictatorial deception and lip-service. Referring to such experience, among other scholars in the region, I repeatedly tried to call the attention of international professional fora to the facts that, firstly, in contrast to the worldview of the traditionally self-closing legal positivism, the genuine nature of law can only be identified outside itself; secondly, the formalism of modern law is only a part of the ideology of the legal profession of the West from the 18th to 20th centuries; consequently, thirdly, extending the scope of formalism as a criterion from the internal sphere of professional deontology to the overall ontology of the legal phenomenon will necessarily conceal the distinctive features of those arrangements that are based on other principles (e.g., on divine revelation in Islamic and Jewish law) or which refer to formalism (e.g., in socialisms) mostly out of mere political-ideological motives. ${ }^{40}$ Or, as the same British comparatists propose (with reference to my own attempt) ${ }^{41}$ the solution is "the multitextuality of the legal cultures" as opposed to the "decontextualised picture" of "comparative law', that is, to rely on "an entire contextual matrix in which the state law operates" (and, in it, also on the "microsocial level of grass-root lived-experience") within the "widely acknowledged [...] field of legal scholarship" of "comparative legal cultures'; bearing the lesson in mind that

\footnotetext{
${ }^{40}$ See, by the author, as a clearly theoretical argument, Is Law a System of Enactments? in: Peczenik, A.-Lindahl, L.-van Roermund, B. (ed.): Theory of Legal Science. DordrechtBoston-Lancaster, 1984. 175-182.; for questions raised in socialism, Law as a Social Issue, in: Wronkowska, S.-Zielinski, M. (ed.): Szkice z teorii prawa i szczególowych nauk prawnych Professorowi Zygmuntowi Ziembinskiemu [Outlines for legal theory: a festschrift for Prof. Zygmunt Ziembinski]. Poznan, 1990. 239-255.; and as the pathology of Socialism and, therefore, also as a claim for laying the foundations for a specifically issue-sensitive legal ontology, Liberty, Equality, and the Conceptual Minimum of Legal Mediation, in: MacCormick, N.-Bankowski. Z. (ed.): Enlightenment, Rights and Revolution Essays in Legal and Social Philosophy. Aberdeen, 1989. ch. 11, 229-251. \{reprinted in Varga, Cs. (ed.): Marxian Legal Theory. Aldershot-Hong Kong-Singapore-SydneyDartmouth-New York, 1993. 501-523.\}. As to the modern law's formalism, seen as a proper professional deontology, that is, as the very form of the law's ontological existence (instead of the merely epistemological perspective of assessing it ideologically, or sheerly ideology-critically as a false consciousness, only motivated by the juristic world-concept [“juristische Weltanschauung”]), see, also Varga, Cs.: The Place of Law in Lukács' World Concept. Budapest, 1985 [reprint 1998]. 193, passim.

${ }^{41}$ Comparative Legal Cultures. op. cit. xvii.
} 
"a living body of law is not a collection of doctrines, rules, terms and phrases. It is not a dictionary, but a culture; and it has to be approached as such." ${ }^{42}$

\section{b) Convergence of Civil Law and Common Law}

As to the convergence of European legal systems, a French-Canadian professor teaching at the Sorbonne in Paris gave voice to his doubts ${ }^{43}$ which later stirred up an aggressive yet all the poorer international debate, ${ }^{44}$ in response to two

${ }^{42}$ Puchalska-Tych-Salter: Comparing Legal Cultures of Eastern Europe... op. cit. 183; 181 , note $114 ; 182$ and note 118 , as well as 182 , referring to Cotterrell, R.: The Concept of Legal Cultures, in: Comparing Legal Cultures. op. cit. 13-32. and Nelken, D.: Who can you Trust? The Future of Comparative Criminology [a lecture presented at the workshop entitled Comparing Legal Cultures. op. cit. \{Macerata, May 18-20, 1994\}], to Comparative Legal Cultures. xv-xxiv as well as Zedner, L.: In Pursuit of the Vernacular: Comparing Law and Order Discourse in England and Germany. Social \& Legal Studies 4 (1995), 517535. Cf. also Friedman, L.: Some Thoughts on Comparative Legal Culture, in: Clark, D. S. (ed.): Comparative and Private International Law. Essays in Honour of John Henry Merryman on his 70th Birthday. Berlin, 1990.

${ }^{43}$ Cf., by Legrand, P.: Europen Legal Systems... op. cit., passim, as well as his Sens et non-sens d'un Code Civil Européen. Revue internationale de Droit comparé 48 (1996), 779 et seq., Against a European Civil Code. Modern Law Review 60 (1997), 44. et seq., and Le primat de la culture, in: P. de Varaeilles-Sommières (ed.): Le droit privé européen. Paris, 1998. 1-5. It is to be mentioned that Markesinis, B. S.-Why a Code is not the Best Way to Advance the Cause of European Legal Unity. European Review of Private Law (1997), 519-524-, acknowledging the unfeasibility of a common code yet wishing to substantiate the convergence, introduced the German law of contracts in English in a series of collective works, adapting the method of 19th-century German pandectism-"first deconstruct and then reconstruct"-to English conditions. This laudable initiative was, however, qualified by its critic-Legrand, P.: Are Civilians Educable? Legal Studies 18 (1998), 216 et seq., particularly at 227, note 63-as the "trivialisation" of German law. Markesinis, in return, gave way to a rejoinder of a personal tone in his Studying Judicial Decisions in the Common Law and the Civil Law: A Good Way of Discovering Some of the Most Interesting Similarities and Differences that Exist between these Legal Families, in: van Hoecke, M.-Ost, F. (ed.): The Harmonisation of European Private Law. OxfordPortland-Oregon, 2000. 117-134, especially 133.

${ }^{44} \mathrm{Cf}$., just for one example, van Hoecke, M.: The Harmonisation of Private Law in Europe: Some Misunderstandings, in: The Harmonisation... op. cit. 1-20 [relying rather idealistically solely on measures of education and socialisation] and, especially, Chamboredon, A.: The Debate on a European Civil Code: For an »Open Texture«, in: ibid., 63-99 [giving a post-modern expression to ancient wisdoms gained from the European experience of codification by combining legislatorial moderation, as well as from raising awareness of the use of flexible concepts and systematic interpretation]. All this was accompanied by such overtones in the overall debate that G. Samuel-English Private Law in the Context of the Codes, in: ibid., 47-felt prompted to state: "Weak theorising, 
resolutions taken by the European Parliament on the commencement of the preparation, respectively actual drafting, of a Common European Code of Private Law, ${ }^{45}$ about which enthusiastic reports were at once released, concluding from the signs of "converging" and "a continual rapprochement" that "a new ius commune is thus in the making". ${ }^{46}$

What are, then, these daring allegations? The description of living complexes in terms of mere rules results in "thin description" at the most, excluding "thick description" the more so as the rules are-just as the concepts-only the outcome of some feasible mental representation. ${ }^{47}$ Thus, any exclusive reliance upon or over-emphasis of them may only contribute to the dissolution of existing interrelations by atomising and fragmenting their organic components. ${ }^{48}$ Since in case of any law "you have to know where it comes from and what its image of itself is", ${ }^{49}$ we can only conclude that there is a difference between Civil Law and Common Law, which is both irreducible and irresolvable at the same

simplistic metaphors and the arrogant dismissal of opponents' arguments do Europe no favours."

45 'European Parliament's Resolution on Action to Bring into Line the Private Law of the Member States' Official Journal C158/400 (26 May 1989) and 'European Parliament's Resolution on the Harmonisation of Certain Sectors of the Private Law of the Member States' Official Journal C205/518 (6 May 1994).

${ }^{46}$ de Groot, G.-R.: European Education in the 21st Century, in: De Witte, B.-Forder, C. (ed.): The Common Law of Europe and the Future of Legal Education. Deventer, 1992, 11; Glenn, H. P.: La civilisation de la common law. Revue internationale de Droit comparé 45 (1993), 567; as well as Markesinis, B. S.: Bridging Legal Cultures. Israel Law Review 27 (1993), 382.

${ }^{47}$ Ryle, G.: The Thinking of Thoughts: What is »Le Penseur « Doing?, in: his Collected Papers II: Collected Essays, 1929-1968. London, 1971. 480, as well as Stengers. I.: Le pouvoir des concepts, in: Stengers, I.-Schlenger, J.: Les concepts scientifiques Invention et pouvoir. Paris, 1991. 63-64. It is to be remarked that the "praesumptio similitudinis", proposed by Zweigert, K.-Kötz, H. in their An Introduction to Comparative Law. 2nd rev. ed. Oxford-New York, 1992. 36, according to which even radical differences in conceptualisation may result in similar functional solutions in practice-as once expressedly observed by Zweigert, K. in his Solutions identiques par des voies différentes (Quelques observations en matières de droit comparé), Revue internationale de Droit comparé XVIII (1966), 5-18-, does not offer a refuge, because it indicates exactly the unsuitability and the barriers of text-formalism.

48 "We have put into people's heads that society is a creature of abstract thought when it is constituted by habits and customs. When you submit habits and customs to the grindstone of reason, you pulverize ways of life based on longstanding traditions and reduce human beings to the state of anonymous and interchangeable atoms." Lévy-Strauss, C.-Eribon, D.: De près et de loin. Paris, 1988. 165.

${ }^{49}$ Merryman, J.: in The American Journal of Comparative Law 35 (1987), 441. 
time. For it is made up of the difference between mentalities and worldviews with their implied presuppositions and attitudes, aspirations and empathies, which all constitute the deep structure and local rationality of thinking in terms of all the above and serve as the indispensable key to their cognition. This is why the classic of studies in Roman law once spoke (as if of the Hegelian Volksgeist) something of a secret intellectuality, ${ }^{50}$ recalling the original idea of Montesquieu: "It is not the body of laws that I am looking for, but their soul!".

\section{Concluding Remarks}

With this, we have returned to the self-closure of 'comparative law'. Although the programmatic methodological requirement according to which "the comparativist must eradicate the preconceptions of his native legal system" 52 is well known, actually it is the Western concepts of order, ethos and rationality that are usually asserted as universal claims under the veil of "a nontransparent and taken-for-granted Western ideology of value-free scientific approach to research". ${ }^{53}$ This is what manifests itself in the global sanctioning of the Western ideal of law $^{54}$ and especially in the service of current Atlantic and European endeavours which deliberately restrict the chances for survival of other ideals of order and legal arrangements, ${ }^{55}$ and also in the competition

${ }^{50}$ Pringsheim, F.: Inner Relationship between English and Roman Law. Cambridge Law Journal (1933-1935), 348.

${ }^{51}$ Montesquieu: Dossier de l'Esprit des Lois. In: Caillois, R. (ed.): Oeuvres complètes II. Paris, 1951. 1025. Legrand: European Legal Systems Are not Converging. op. cit. 55 et seq. explains in more detail the impossibility of convergence by the example of the radical differences both in legal reasoning and systematisation, and the use of rules and the role of facts, as well as the in meaning of entitlements and the varying presence of the past.

${ }^{52}$ Zweigert-Kötz: An Introduction to Comparative Law. op. cit. 32.

${ }^{53}$ Puchalska-Tych-Salter: Comparing Legal Cultures of Eastern Europe... op. cit. 160.

${ }^{54}$ For a stand taken by legal philosophy, see, e.g., Surya Prakash Sinha: Non-universality of Law. Archiv für Rechts- und Sozialphilosophie 81 (1995). 185-214. According to his radical conclusion, "law itself is parochial to Western civilisation", therefore "transforming non-legal cultures into legal societies", as forced by the majority of international organisations, is both harmful (as it evacuates cultural patterns) and subversive for the larger part of the world (209 and 211).

${ }^{55}$ One of the fields of such fights today is the question of the universalisability, without a cultural loss, of human rights, taken as an ideal and as a store of instruments enacted by Atlantic documents in accordance with the Western legal ideal. See, e.g., Pollis, A.-Schwab, P. (ed.): Human Rights Cultures and Ideological Perspectives. New York, 1979.; Surya Prakash Sinha: Human Rights: A Non-western Viewpoint. Archiv für Rechts- 
for patterning the future European law through the re-writing of its past history ${ }^{56}$ in short, which manifests itself in all preferences called ethnocentrism in

und Sozialphilosophie 67 (1981), 76 et seq.; Hassan, R.: On Human Rights and the Qur'anic Experience, and Mitra, K.: Human Rights in Hinduism. Journal of Ecumenical Studies 19 (1982), 51-65, resp. 77-84; Hjärpe, J.: The Contemporary Debate in the Muslim World on the Definition of »Human Rights «. In: Ferdinand, K.-Mozaffari, M. (ed.): Islam State and Society. London, 1988. 26-38.; Welsh, C. Jr.-Leary, V. (ed.): Asian Perspectives on Human Rights. Boulder, 1990.; Preis, A.-B. S.: Human Rights as Cultural Practice: An Anthropological Critique. Human Rights Quarterly 18 (1996), 286-315.; Dembour, M.-B.: Human Rights Talk and Anthropological Ambivalence: The Particular Contexts of Universal Claims. In: Harris, O. (ed.): Inside and Outside the Law Anthropological Studies of Authority and Ambiguity. New York-London, 1996. ch. 2, 19-40; Luf, G.: Peace and Human Rights as Seen by the Churches. In: Bsteh, A. (ed.): Peace for Humanity Principles, Problems and Perspectives of the Future as Seen by Muslims and Christians. New Delhi, 1996. 143-157 and, for the debate, 158-177.; Lindholt, L.: Questioning the Universality of Human Rights The African Charter on Human and Peoples' Rights in Botswana, Malawi and Mozambique. Aldershot-Burlington USA-Singapore-Sydney, 1997.; Marfording, A.: Cultural Relativism and the Construction of Culture: An Examination of Japan. Human Rights Quarterly 19 (1997) 3, 431-448.; Perry, M. J.: Are Human Rights Universal? The Relativist Challenge and Related Matters. Human Rights Quarterly 19 (August 1997), 461509.; Boaventura de Sousa Santos: Toward a Multicultural Conception of Human Rights. Sociologia del Diritto XXIV (1997), 27-45.; Hjärpe, J.: Some Problems in the Meeting between European and Islamic Legal Tradition Examples from the Human Rights Discussion [multipl.]. [Lund:] [n.y.] 21. The set of questions naturally involves interference through exerting political or economic pressure or via so-called humanitarian aid. For Central and Eastern Europe, see the titles in note 39 and, for an example distant but touching upon so called "Westernisation strategies", Wai Man Sin-Chu Yiu Wai: Whose Rule of Law? Rethinking (Post-)Colonial Legal Culture in Hong Kong. Social \& Legal Studies 7 (1998). 147-169.

${ }^{56}$ After remarkable historical foundation-above all, by Koschaker, P.: Europa und das römische Recht. München, 1947. and Wieacker, F.: Privatrechtsgeschichte der Neuzeit unter besonderer Berücksichtigung der deutschen Entwicklung. Göttingen-VandenhoeckRuprecht, 1952.-and serials-first of all, Coing, H. (hrsg.): Handbuch der Quellen und Literatur der neueren Europäischen Privatrechtsgeschichte München, 1973-1988. and Ius commune I-(1973-)-, accompanied by theoretical overviews-e.g., Wieacker, J.: Foundations of European Legal Culture. The American Journal of Comparative Law 38 (1990), 129., Arnaud, A.-J.: Pour une pensée juridique européenne. Paris, 1991., as well as Gessner, V.-Hoeland, A.-Varga, Cs.: European Legal Cultures. Aldershot-Brookfield USASingapore-Sydney, 1996., a discipline called 'European legal history' was born. For its outlines, see, e.g., Schulze, R. (hrsg.): Europäische Rechts- und Verfassungsgeschichte Ergebnisse und Perspektiven der Forschung. Berlin, 1991. and Schulze, R.: European Legal History: A New Field of Research in Germany. The Journal of Legal History 13 (1992). 270-295. According to critics-e.g., Osler, D. J.: The Myth of European Legal History. 
scholarship, cultural imperialism in politics, and neo-colonialism in practice. In fact, in the absence of any theoretically elaborated or methodologically founded opposing force, all such impacts have recently been marshalled mostly under the banner of 'comparative law' or at least with its active support.

Nevertheless, we have to bear in mind that no kind of formalism can serve as an excuse for any restrictions on human entirety and cultural diversity, as well as on the professional responsibility to be taken for these. ${ }^{57}$ Accordingly, in our approach to legal institutions we also have to recognise individual and collective accomplishments in all human attempts at creating order, and provided they have produced values, we have to appreciate and try to preserve these as such. ${ }^{58}$

Rechtshistorisches Journal 16, 393-410-, all this endeavour dedicated to erecting a 'European legal history' has only been conceived as to re-write history according to present-day interests, so as to conclude, by justifying the alleged past existence of a ius commune by the one-time allegedly dominant intellectual performance of today's major European powers, to the advent of a ius commune in the European Union with a hegemonic role to be played in its framing by a German-Dutch-French bloc. For the pitfalls (with underlying methodological biases) of such a new Euro-historicism, see, among others, Anton Schuurman, A.: Globalisering en geschiedenis. Tijdschrift voor sociale geschiedenis 27 (2001), 385-410.; Borgolte, M.: Vor dem Ende der Nationalgeschichten? Chancen und Hindernisse für eine Geschichte Europas im Mittelalter. Historische Zeitschrift (2001), 561-596.; and Hoenicke Moore, M E.: Euro-Medievalism: Modern Europe and the Medieval Past. Collegium (Summer 2002), 67-79.

${ }^{57}$ Cf. Zacher, H. F. (ed.): Democracy Some Acute Questions [The Proceedings of the Fourth Plenary Session of the Pontifical Academy of Social Sciences, 22-25 April 1998] Vatican City, 1999. and Zacher, H. F. (ed.): Democracy Reality and Responsability [The Proceedigns of the Sixth Plenary Session of the Pontifical Academy of Social Sciences, 23-26 February 2000], Vatican City, 2001.

${ }^{58}$ For a number of further related questions, cf. Krawietz, W.-Varga, Cs. (ed.): On Different Legal Cultures, Pre-Modern and Modern States, and the Transition to the Rule of Law in Western and Eastern Europe. Berlin, [2003]. Rechtstheorie 33 (2002) 2-4. 